\title{
PENGARUH PEMBELAJARAN REACT TERHADAP KEMAMPUAN BERPIKIR KRITIS MATEMATIS DITINJAU DARI HABIT OF MIND MAHASISWA
}

\author{
Meyta Dwi Kurniasih \\ Universitas Muhammadiyah Prof. DR. HAMKA \\ mey_mathholic@yahoo.com
}

\begin{abstract}
ABSTRAK
Tujuan penelitian ini adalah mengetahui pengaruh metode pembelajaran REACT terhadap kemampuan berpikir kritis matematis mahasiswa calon guru. Penelitian ini dilakukan di program studi Pendidikan Matematika Universitas Muhammadiyah Prof DR HAMKA. Desain penelitian yang digunakan adalah treatment by level $2 \times 2$, dengan variabel bebas adalah metode pembelajaran yaitu REACT dan konvensional, variabel terikat adalah kemampuan berpikir kritis matematis, dan variabel moderator adalah habit of mind. Teknik pengambilan sampel yang digunakan cluster random sampling. Hasil penelitian ini adalah pertama pembelajaran REACT efektif untuk meningkatkan kemampuan berpikir kritis matematis mahasiswa sehingga metode ini dapat digunakan dalam perkuliahan Analisis Real bagi calon guru matematika. Kedua, pembelajaran berpengaruh terhadap kemampuan berpikir kritis matematis mahasiswa tergantung dengan habit of mind mahasiswa. Ketiga, perkuliahan dengan pembelajaran REACT mahasiswa yang memiliki habit of mind tinggi memiliki skor kemampuan berpikir kritis yang lebih tinggi dibandingkan dengan perkuliahn konvensional. Uji selanjutnya diharapkan untuk menentukan metode pembelajaran yang tepat untuk mahasiswa yang memiliki habit of mind rendah.
\end{abstract}

Kata Kunci : REACT, Kemampuan Berpikir Kritis Matematis, Habit of Mind

\section{PENDAHULUAN}

Pendidikan matematika merupakan sebuah proses belajar mengajar matematika yang wajib di setiap jenjang pendidikan formal. Pemerintah dewasa ini terus meningkatkan mutu pendidikan termasuk pendidikan matematika melalui berbagai inovasi baik sistem pendidikan, kurikulum, buku ajar, metode pembelajaran dan peningkatan kualitas guru. Peningkatan kualitas guru menjadi hal yang penting, karena guru sebagai ujung tombak dalam proses pembelajaran di sekolah. Upaya perbaikan ini dimulai dari bangku kuliah. Calon guru matematika harus diberi bekalan yang cukup baik dalam hal pedagogik, profesionalitas, sosial dan kepribadian, sehingga akan menjadi guru yang berkualitas nasional bahkan internasional.

Salah satu bekal yang diberikan untuk calon guru matematika adalah kemampuan berpikir kritis matematis. Menurut Ennis (2000), kemampuan berpikir kritis matematis adalah berpikir secara beralasan dan reflektif dengan menekankan pembuatan keputusan 
tentang apa yang harus dipercaya atau dilakukan. Hal ini berkaitan dengan informasi yang didapatkan dari hasil pengalaman, pengamatan, penggunaan akal sehat atau komunikasi antar manusia. Kemampuan berpikir kritis matematis dapat dikembangkan melalui pembelajaran di perguruan tinggi yang menekankan pada sistem struktur, konsep, serta keterkaitan antara unsur. Analisis real meruapakan mata kuliah yang menitikberatkan pada kemampuan berpikir kritis mahasiswa. Karena dalam mata kuliah ini mahasiswa dilatih untuk memverifikasi sebuah pernyataan, dan menjelaskannya dalam bahasa yang logis dan sistematis.

Pembelajaran REACT merupakan salah satu pembelajaran yang meningkatkan kemampuan berpikir kritis matematis mahasiswa, karena pembelajaran ini menekankan lima tahapan yaitu mengaitkan (relating), mengalami (experiencing), menerapkan (applying), bekerjasama (cooperating), mentransfer (transferring). Lebih lanjut Wardani dan Meyta (2014) menyatakan bahwa, REACT strategy requires students to be active in learning so that the students' memory on what have been learned will last longer." Jadi dengan pembelajaran aktif, maka kemampuan berpikir kritis mahasiswa akan lebih terasah. Selain model pembelajaran, hal lain yang perlu mendapat perhatian terhadap keberhasilan belajar mahasiswa adalah perbedaan individu yaitu mengenai habit of mind (kebiasaan berpikir). Penggunaan habit of mind lebih mengembangkan kemampuan siswa dalam memproduksi pengetahuan. Habit of mind salah satunya dapat diwujudkan dengan kebiasaan koginitif (cognitive habituation).

\section{Kemampuan Berpikir Kritis Matematis Mahasiswa}

Matematika merupakan ilmu yang mengajarkan berpikir logis dan terstruktur. Seringkali, matematika sebagai ilmu pasti dianggap monoton dan kurang mengembangkan kreativitas individu. Namun, mempelajari bidang apapun khususnya matematika, setiap orang tidak terlepas dari proses berpikir. Berpikir yang dimaksud meliputi dua aspek yaitu kritis dan kreatif. Lebih lanjut Alamsyah dan Turmudi (2017) menyatakan bahwa kemampuan berpikir matematis yang tergolong dalam tingkat tinggi diantaranya adalah kemampuan berpikir kritis dan kreatif. Oleh karena itu, tujuan pelajaran matematika tidak sekedar memahami, tapi penguasaan kemampuan yang lebih tinggi yaitu kemampuan berpikir kritis.

Kemampuan berpikir kritis matematis sangat dibutuhkan karena perkembangan zaman dan ilmu pengetahuan, pembelajaran matematika mengarah pada pemahaman dan 
menganalisis konsep-konsep yang diperlukan untuk menyelesaikan masalah matematika dan ilmu pengetahuan lainnya yang lebih efektif. Berpikir kritis tersebut bisa muncul apabila dalam pembelajaran adanya masalah yang menjadi memicu dan diikuti dengan pertanyaan: Menyelesaikan soal itu dengan cara yang lain, "Mengajukan pertanyaan bagaimana jika; Apa yang salah", dan "Apa yang akan kamu lakukan"” (Krulik dan Rudnick dalam Somakim, 2011). Berpikir kritis matematis merupakan dasar proses berpikir untuk menganalisis argumen dan memunculkan gagasan terhadap tiap makna untuk mengembangkan pola pikir secara logis (Jumaisaroh, 2014). Oleh karena itu, mahasiswa harus terbiasa dengan permasalahan matematika yang memuat proses berpikir logis, sehingga kemampuan berpikir kritisnya semakin terasah pula.

Berpikir kritis penting bagi masa depan siswa, mengingat bahwa itu mempersiapkan siswa untuk menghadapi banyak tantangan yang akan muncul dalam hidup mereka, karir dan pada tingkat kewajiban dan tanggung jawab pribadi mereka (Tsui, dalam Vieira, Tenreiro-Vieira, Martins, 2011). Berpikir kritis merupakan aktivitas penalaran yang berdasarkan kajian, lalu di analisa sebab dan bagaimana selanjutnya. Mahasiswa yang mampu berpikir kritis, mahasiswa dapat mengemukakan ide, argumen berdasarkan teori-teori sebelumnya. Jadi, mahasiswa tidak hanya menerima secara mentah informasi yang diperoleh, tetapi dipahami betul dan analisa.

Membiasakan untuk berpikir kritis memang butuh waktu dan pembiasaan. Umumnya, di sekolah pembelajaran berlangsung teacher centre sehingga peserta didik kurang diberi kesempatan untuk mengeksplorasi kemampuannya. Keterampilan berpikir kritis matematis sangat penting bagi siswa karena dengan keterampilan ini siswa mampu bersikap rasional dan memilih alternatif pilihan yang terbaik bagi dirinya. Selain itu, menanamkan kebiasaan berpikir kritis matematis bagi pelajar perlu dilakukan agar mereka dapat mencermati berbagai persoalan yang terjadi dalam kehidupan sehari-hari (Somakim, 2011).

\section{Pembelajaran REACT}

Perkembangan ilmu pengetahuan dan teknologi, menuntun manusia untuk selalu melakukan berbagai inovasi dalam kehidupan. Inovasi dalam dunia pendidikan matematika salah satunya yang dikemukakan oleh CORD (1999) yaitu tentang pembelajaran REACT. Akronim REACT menjelaskan lima komponan yang dapat digunakan, yaitu: Relating (mengaitkan), Experiencing (mengalami), Applying (menerapkan), Cooperating 
(bekerjasama), Transferring (mentransfer) (Kusaeni, 2013). Oleh karena itu, REACT merupakan rangkaian kegiatan yang dilakukan oleh dosen dan mahasiswa dalam pembelajaran yang mengimplementasikan lima komponen yaitu mengkaitkan, mengalami, menerapkan, bekerjasama dan mentransfer pengetahuan yang didapatkan.

Relating (mengaitkan) adalah pembelajaran dengan mengaitkan materi yang sedang dipelajarinya dengan konteks pengalaman kehidupan nyata atau pengetahuan yang sebelumnya. Menurut Dimyati dan Mudjiono (2006:105), "guru wajib menggunakan pengalaman belajar dan kemampuan siswa dalam mengelola siswa." Dalam hal ini dosen/pengajar diharapkan dapat memotivasi mahasiswa agar mampu mengaitkan materi yang telah didapat sebelumnya dengan materi yang akan dipelajari. Jadi, diharapkan mahasiswa memiliki peta konsep yang baik mengenai keterkaitan antara materi matematika. Experiencing (mengalami) merupakan merupakan pembelajaran yang membuat mahasiswa belajar dengan melakukan kegiatan matematika (doing math) melalui eksplorasi, penemuan dan pencarian. Dengan mengalami maka dapat membantu mahasiswa untuk memahami konsep baru dengan cara mengkonstruksikan pengalamanpengalaman yang terjadi di dalam kelas melalui eksplorasi, pencarian dan penemuan, pengalama ini bisa mencakup penggunaan manipulasi, pemecahan masalah dan aktifitas di laboratorium (Crawford, 2001).

Pembelajaran REACT bukanlah suatu tahapan-tahapan yang harus dilakukan secara berurutan atau semua komponan yang ada harus dilakukan dalam sebuah pembelajaran di kelas. Namun, disesuai dengan kebutuhan pembelajaran yang dilakukan. Pembelajaran REACT dapat dilaksanakan mengikuti rancangan yang dibutuhkan dalam pembelajaran sehingga pembelajaran yang terjadi lebih variatif dan menantang mahasiswa.

\section{Habit of Mind}

Habit of Mind yang dalam Bahasa Indonesia berarti kebiasaan berpikir, awalnya dikembangkan oleh Costa dan Kallick tahun 1985. Menurut Costa dan Kallick (2012), habit of mind adalah berprilaku cerdas, yaitu prilaku ketika dihadapkan permasalahan yang solusinya tidak dapat diketahui dengan mudah. Penggunaan habit of mind lebih mengembangkan kemampuan siswa dalam memproduksi pengetahuan. Selain itu pola prilaku cerdas lebih memungkinkan bertindak produktif, ketika menghadapi dikotomi, dibuat bingung oleh dilemma, atau bertatap muka dengan ketidakpastian. Habit of mind salah satunya dapat diwujudkan dengan kebiasaan koginitif (cognitive habituation). 
Kaitannya dengan kebiasaan kognitif, hal ini tidak terlepas dari potensi kecerdasan yang dimiliki oleh setiap individu (IQ). Jadi pembiasaan kognitif perlu diselaraskan dengan $I Q$ masing-masing individu, sehingga secara praktis pembiasaan ini dapat berbeda untuk setiap orang disesuaikan dengan $I Q$ nya masing-masing.

Upaya mengaplikasikan habit of mind dalam matematika perlu dipahami terlebih dahulu oleh dosen bahwa dalam pembelajaran matematika terhadap mahasiswa tidak hanya tingkat kedalaman konsep yang diberikan pada mahasiswa, tetapi harus disesuaikan pula dengan tingkat kemampuannya. Hal inilah yang merupakan kunci keberhasilan dalam menerapkan habit of mind dalam pembelajaran matematika. Lebih lanjut Vass (2013) menyebutkan beberapa cara untuk melakukannya yaitu: 1) latihan berpikir, 2) mencari informasi, 3) mengumpulkan pengalaman melalui virtual, dan 4) melakukan aktivitas yang baru. Jadi diharapkan dengan keempat langkah tersebut mahasiswa calon guru memiliki habit of mind yang kuat yang memungkinkannya untuk dapat bepikir secara kritis, berpikir kreatif, dan dapat mengatur perilaku dirinya sendiri.

Menurut Cole (dalam Vass, 2013), lingkungan merupakan aspek penting dalam membentuk kebiasaan hidup manusia. Jadi jika pada lingkungan pendidikan mahasiswa dilatih atau di biasakan untuk berpikir terhadap hal-hal dari yang sederhana, maka berpikir akan menjadi budaya akademik. Oleh sebab itu, dosen harus dapat memilih model pembelajaran yang tepat bagi mahasiswanya. Dimana pembelajaran yang tidak hanya sekedar transfer ilmu pengetahuan tapi juga menanamkan kebiasaan berpikir (habit of mind) mahasiswa.

Sehubungan dengan kebiasaan berpikir, Costa dan Kallick (dalam Campbell, 2014) mengidentifikasi 16 indikator yang merupakan karakteristik yang muncul ketika seseorang berhadapan dengan masalah yang pemecahannya tidak segera diketahui yaitu Persisting, Managing impulsivity, Listening with understanding and empaty, Thinking flexibly, Metacognition, Striving for accuracy, Questioning and problem possing, Applying past knowledge to new situations, Thinking and communicating with crarity and precision, Gathering data through all sense, Creating, imagining and innovating, Responding with wonderment and awe, Taking responsible risk, Finding humor, Thinking interdependently dan Remaining open to continuous learning.

Berdasarkan uraian di atas, maka dapat yang dimaksud habit of mind adalah karakteristik siswa berperilaku cerdas ketika menghadapi masalah atau jawaban yang tidak segera diketahui dalam proses pembelajaran melalui pengaturan diri, berpikir kritis, 
dan berpikir kreatif dengan cara menyadari pemikirannya sendiri, membuat rencana secara efektif, menyadari dan menggunakan sumber-sumber informasi yang diperlukan, sensitif terhadap umpan balik, mengevaluasi keefektifan tindakan, bersikap akurat dan mencari akurasi, jelas dan mencari kejelasan, bersifat terbuka, menahan diri dari sifat impulsif, sensitif terhadap perasaan dan kemampuan teman, melibatkan diri dalam tugas meskipun jawaban dan solusinya tidak segera tampak, berusaha memaksimalkan kemampuan dan pengetahuan, menghasilkan, membuat dan memperbaiki standar evaluasi, menghasilkan cara baru dalam melihat situasi yang berada di masyarakat.

\section{METODE PENELITIAN}

Penelitian ini merupakan penelitian eksperimen dengan variabel terikat adalah kemampuan berpikir kritis matematis mahasiswa dan variabel bebas terdiri dari variabel perlakuan dan variabel moderator. Variabel perlakuan adalah pembelajaran $\operatorname{REACT}\left(\mathrm{A}_{1}\right)$ dan pembelajaran konvensional $\left(\mathrm{A}_{2}\right)$. Variabel moderator adalah habit of mind mahasiswa yang terdiri dari habit of mind tinggi $\left(\mathrm{B}_{1}\right)$ dan habit of mind rendah $\left(\mathrm{B}_{2}\right)$. Penelitian ini dirancang percobaannya dengan menggunakan desain treatment by level $2 \times 2$, seperti pada Tabel 1 berikut:

Tabel 1. Desain Penelitian dengan Treatment by Level 2x2

\begin{tabular}{ccc}
\hline Habit of Mind & \multicolumn{2}{c}{ Metode Pembelajaran $(\mathrm{A})$} \\
\cline { 2 - 3 }$(\mathrm{B})$ & REACT $\left(\mathrm{A}_{1}\right)$ & Konvensional $\left(\mathrm{A}_{2}\right)$ \\
\hline Tinggi $\left(\mathrm{B}_{1}\right)$ & $\mathrm{A}_{1} \mathrm{~B}_{1}$ & $\mathrm{~A}_{2} \mathrm{~B}_{1}$ \\
Rendah $\left(\mathrm{B}_{2}\right)$ & $\mathrm{A}_{1} \mathrm{~B}_{2}$ & $\mathrm{~A}_{2} \mathrm{~B}_{2}$ \\
\hline
\end{tabular}

Keterangan:

$\mathrm{A}_{1} \mathrm{~B}_{1}$ : Skor kemampuan berpikir kritis matematis pada kelompok mahasiswa yang memperoleh pembelajaran REACT dengan habit of mind tinggi

$\mathrm{A}_{1} \mathrm{~B}_{2}$ : Skor kemampuan berpikir kritis matematis pada kelompok mahasiswa yang memperoleh pembelajaran REACT dengan habit of mind rendah

$\mathrm{A}_{2} \mathrm{~B}_{1}$ : Skor kemampuan berpikir kritis matematis pada kelompok mahasiswa yang memperoleh pembelajaran Konvensional dengan habit of mind tinggi

$\mathrm{A}_{2} \mathrm{~B}_{2}$ : Skor kemampuan berpikir kritis matematis pada kelompok mahasiswa yang memperoleh pembelajaran Konvensional dengan habit of mind rendah

Populasi dalam penelitian ini adalah populasi target seluruh mahasiswa Pendidikan Matematika di Univeritas Muhammadiyah Prof DR HAMKA tahun ajaran 2016/2017, 
populasi terjangkaunya mahasiswa Pendidikan Matematika Semester V pada mata kuliah Analisis Real. Teknik pengambilam sampel dilakukan dengan Cluster Randomized Sampling. Mahasiswa yang mengikuti mata kuliah ini ada kelas 5 kelas. Dari 5 kelas diambil 2 kelas secara acak yaitu kelas 5-E dan kelas 4-F dimana untuk kelas 4-E terdiri dari 38 mahasiswa dan kelas 4-F terdiri dari 30 mahasiswa. Dari kedua kelas ditentukan secara acak untuk dijadikan kelas eksperimen dan kelas kontrol, yaitu kelas 4-F sebagai kelas eksperimen yang mendapat pembelajaran REACT dan kelas 4-E sebagai kelas kontrol dengan pembelajaran konvensional. Kemudian setelah melakukan pemberian angket habit of mind, penentuan kelompok habit of mind tinggi dan habit of mind rendah dilakukan dengan menyusun urutan responden berdasarkan skor angket habit of mind yang diperoleh, yaitu skor tertinggi hingga skor terendah. Untuk mendapatkan kelompok tinggi dan kelompok rendah S. Naga (2012) mengemukakan, ukuran untuk menentukan kelompok tinggi dan kelompok rendah adalah $33 \frac{1}{3} \% \quad M_{T}=M_{R}=33 \frac{1}{3} \%$ ) dimana angka ini cukup kontras dan reliabel. Jadi, sampel penelitian ini terdiri dari dua kelas, yang masing-masing kelas dibagi menjadi dua kelompok, dengan menggambil $33 \frac{1}{3} \%$ mahasiswa habit of mind tinggi dan $33 \frac{1}{3} \%$ mahasiswa habit of mind rendah.

Instrumen kemampuan berpikir kritis matematis berbentuk tes essai. Instrumen terdiri mengukur materi barisan bilangan real. Respon peserta divaliditas isi 8 orang pakar pendidikan matematika untuk melihat kesesuaian butir dengan indikator, kebenaran materi, kontruksi dan bahasa. Untuk menghitung validitas butir tes yang dilakukan menggunakan formulasi yang dikembangkan oleh Lawse (Naga, 2012:316). Hasil pengujian validasi isi menunjukkan bahwa lima butir soal kemampuan berpikir kritis matematis $C V R>0,05$, yang artinya keempat butir valid. Sedangkan nstrumen habit of mind yang dikembangkan berbentuk skala likert dengan 5 pilihan yang terdiri dari 30 butir yang valid. Instrumen terdiri dari tiga dimensi. Respon responden dianalisis untuk menguji validasi dan reabilitas dari instrumen yang akan digunakan

\section{HASIL DAN PEMBAHASAN}

Setelah melakukan penelitian, data hasil penelitian di analisis dan menunjukkan bahwa skor rata-rata kemampuan berpikir kritis matematis mahasiswa yang menggunakan pembelajaran REACT sebesar 57,91 lebih tinggi dibanding yang menggunakan 
pembelajaran konvensional sebesar 48. Sedangkan untuk skor rata-rata kemampuan berpikir kritis matematis mahasiswa pada kelompok $A_{1} B_{1}, A_{1} B_{2}, A_{2} B_{1}$ dan $A_{2} B_{2}$ berturutturut 65,$08 ; 48,60 ; 42,62 ; 55$. Lebih lengkap dapat dilihat pada Tabel 1 berikut:

Tabel 1. Skor Rata-rata Kemampuan Berpikir Kritis Matematis Mahasiswa

\begin{tabular}{cccc}
\hline \multirow{2}{*}{ Habit of Mind } & \multirow{2}{*}{ Statistik } & \multicolumn{2}{c}{ Metode Pembelajaran } \\
\cline { 3 - 4 } & $\mathrm{N}$ & 13 & Konvensional \\
\hline \multirow{2}{*}{ Tinggi $\left(\mathrm{B}_{1}\right)$} & Rata-rata & 65,08 & 13 \\
& $\mathrm{~N}$ & 10 & 42,62 \\
Rendah $\left(\mathrm{B}_{2}\right)$ & Rata-rata & 48,60 & 10 \\
& $\mathrm{~N}$ & 23 & 55,00 \\
Jumlah & Rata-rata & 57,91 & 23 \\
& & & 48,00 \\
\hline
\end{tabular}

Dari hasil penelitian ini menunjukkan selisih rentang skor rata-rata kemampuan berpikir kritis matematis mahasiswa menunjukkan bahwa terdapat perbedaan kemampuan berpikir kritis matematis mahasiswa pada kedua kelas. Pernyataan ini di dukung dengan hasil pengujian dengan menggunakan anava dua jalur, membandingkan skor kemampuan berpikir kritis matematis mahasiswa pada kelompok $A_{1}$ dan $A_{2}$ diperoleh sig. $=0,00<0,05$ $=\alpha$ dan skor pada kelompok $\mathrm{A}_{1}$ lebih tinggi dari kelompok $\mathrm{A}_{2}$. Ini berarti skor kemampuan berpikir kritis matematis kelompok mahasiswa yang menggunakan pembelajaran REACT $\left(\mathrm{A}_{1}\right)$ lebih tinggi dari skor kemampuan berpikir kritis matematis mahasiswa yang menggunakan pembelajaran konvensional $\left(\mathrm{A}_{2}\right)$ menjadi temuan pertama dalam penelitian ini. Ini menunjukkan bahwa pemberian pembelajaran REACT lebih efektif meningkatkan kemampuan berpikir kritis matematis mahasiswa.

Hasil pengujian interaksi antara metode pembelajaran dan habit of mind $(\mathrm{A} * \mathrm{~B})$ diperoleh sign. $=0,000<\alpha=0,05$, ini berarti terdapat interaksi metode pembelajaran dan habit of mind terhadap skor kemampuan berpikir kritis matematis. Jadi temuan kedua dalam penelitian yaitu bahwa adanya interaksi membuktikan bahwa masing-masing pembelajaran memberi pengaruh yang berbeda terhadap kemampuan berpikir kritis matematis mahasiswa jika diterapkan pada kelompok mahasiswa yang memiliki tingkat habit of mind yang berbeda pula. Hal ini berarti dapat dilanjutkan dengan pengujian hipotesis untuk pengaruh sederhana (simple effect).

Pengujian hipotesis selanjutnya menggunakan uji Post Hoc. Karena nilai homogenitis menunjukkan sig. > 0,05 pada semua variabel, maka masing-masing pengaruh variabel independen terhadap variabel dependen menggunakan uji Benferroni. Hasil pengujian menunjukkan untuk kelompok $\mathrm{A}_{1} \mathrm{~B}_{1}$ dan $\mathrm{A}_{2} \mathrm{~B}_{1}$ nilai sig. $=0,000<0,05=\alpha$ dan skor $\mathrm{A}_{1} \mathrm{~B}_{1}$ lebih tinggi dari $\mathrm{A}_{2} \mathrm{~B}_{1}$. Artinya skor kemampuan berpikir kritis matematis 
mahasiswa dengan habit of mind tinggi yang menggunakan pembelajaran REACT lebih tinggi dibandingkan pembalajaran konvensional. Namun, hasil berbeda untuk kelompok $\mathrm{A}_{1} \mathrm{~B}_{2}$ dan $\mathrm{A}_{2} \mathrm{~B}_{2}$ nilai sig. $=0,185>0,05$, tidak terdapat perbedaan yang signifikan antara skor kemampuan berpikir kritis matematis mahasiswa dengan habit of mind rendah yang menggunakan pembelajaran REACT lebih tinggi dibandingkan pembalajaran konvensional.

Telah dipaparkan di atas, bahwa penggunaan pembelajaran REACT lebih efektif meningkatkan kemampuan berpikir kritis matematis. Learning with REACT strategy requires students to be active in the process of Relating, Experiencing, Applying, Cooperating, Transferring (Wardani \& Meyta, 2014). Dengan lima proses yang terjadi dalam aktvitas belajar maka pembelajaran akan lebih mudah untuk diikuti.

Habit of Mind atau kebiasaan berpikir adalah berprilaku cerdas. Lebih lanjut Costa dan Kallick (dalam Djaali, 2008) menyatakan bahwa berpikir cerdas yaitu prilaku ketika dihadapkan permasalahan dapat diketahui dengan mudah. Habit of mind dapat menjadi bekal untuk mahasiswa dalam memproses pemikirannya. Mahasiswa dengan habit of mind tinggi belajar dengan REACT akan meningkatkan kemampuan berpikir kritis matematisnya.

\section{KESIMPULAN}

Kemampuan berpikir kritis matematis merupakan kemampuan matematik yang penting untuk dimiliki mahasiswa. Pembelajaran REACT merupakan salah satu metode pembelajaran yang akan membantu mahasiswa meningkatkan kemampuan berpikir kritis matematisnya, dibandingkan pembelajaran konvensional.

Perbedaan individu seperti habit of mind, memberikan pengaruh yang signifikan pada kemampuan berpikir kritis matematis mahasiswa. Lebih lanjut, untuk mahasiswa dengan habit of mind tinggi jika diberi pembelajaran REACT rata-rata kemampuan berpikir kritisnyanya lebih tinggi dibandingkan yang diberi pembelajaran konvensional. Sedangkan untuk mahasiswa dengan habit of mind rendah, hasil uji statistik menunjukkan tidak ada perbedaan antara kelompok mahasiswa yang menggunakan pembelajaran REACT dan pembelajaran konvensional. Oleh sebab itu, dibutuhkan studi lanjutan untuk menentukan pembelajaran yang tepat untuk kelompok mahasiswa dengan habit of mind rendah.

Dari penelitian ini di harapkan dosen dalam memberikan pelayanan pendidikan kepada mahasiswanya, tidak hanya memperhatikan hasil belajar, namun juga 
memperhatikan kemampuan matematis yang lebih tinggi. Dosen juga diharapkan dapat menerapkan pembelajaran REACT dalam proses perkuliahan, untuk kemampuan berpikir kritis matematis mahasiswanya, yang nantinya akan berdampak pula pada peningkatan prestasi belajar mahasiswanya.

\section{REFERENSI}

Alamsyah, T.P \& Turmudi. (2017). Kemampuan Berpikir Kritis dan Kreatif Serta SelfEsteem Matematis Siswa Melalui Model Advance Organizer. Jurnal Kalamatika Vol.1 No. 2, November 2016. Jakarta: UHAMKA PRESS.

Campbell, J. (2014, 3 April). Theorising Habits of Mind as A Framework of Learning. [On-line]. Tersedia: http://www.aare.edu.au/06pap/cam06102.pdf.

Costa, A. \& Kallick, B. (2012). Belajar dan Memimpin dengan Kebiasaan Pikiran. Jakarta: PT Indeks.

CORD. (1999). Teaching Mathematics Contextually. USA: CORD.

Crawford, M. (2001). Teaching Contextually: Research, Rationale, and Techniques for Improving Student Motivation and Achievement in Mathematics and Science. USA: CORD.

Dimyati \& Mudjiono. (2006). Belajar dan Pembelajaran. Jakarta: PT Rineka Cipta.

Djaali. (2008). Psikologi Pendidikan. Jakarta: Bumi Aksara.

Ennis, R.H. (2000). A Super-Streamlined Coonception of Critical Thinking. Diperoleh dari http://www.criticalthinking.net/ssConcCTApr3.html (2010, 15 April).

Jumaisaroh, T., dkk. (2014). Peningkatan Kemampuan Berpikir MAtematis dan Kemandirian Belajar Siswa SMP melalui Pembelajaran Berbasis Masalah. Jurnal Kreano MIPA, 5(2), 157-169.

Kusaeni, I. (2013). Penerapan Pembelajaran Strategi REACT untuk Meningkatkan Pemahaman Materi Peluang pada Siswa kelas XI Akuntansi 2 SMK Negeri 1 Tarakan. Tesis Universitas Negeri Malang. Tidak Diterbitkan.

Naga, D.S. (2012) Teori Skor pada Pengukuran Mental. Jakarta: PT Nagarani Citrayasa.

Somakim. (2011). Peningkatan Kemampuan Berpikir Kritis Matematis Siswa Sekolah Menengah dengan Penggunaan Pendidikan Matematika Realistik. Jurnal Forum MIPA, 14(1), 42-48.

Vass, E. (2013, 12 April). New technology and habits of mind. Diperoleh dari http://www.beyondcurrenthorizons.org.uk.

Vieira, R. M., Tenreiro-Vieira, C., \& Martins, I. P. (2011). Critical Thinking: Conceptual Clarification and Its Importance in Science Education. Science Education International. 22(1), 43-54.

Wardani, R \& Meyta DK. (2014). The influence of react strategy towards mathematical belief. Procceding International Seminar on Innovation in Mathematics and Mathematics Education 1st. Yogyakarta: UNY. 